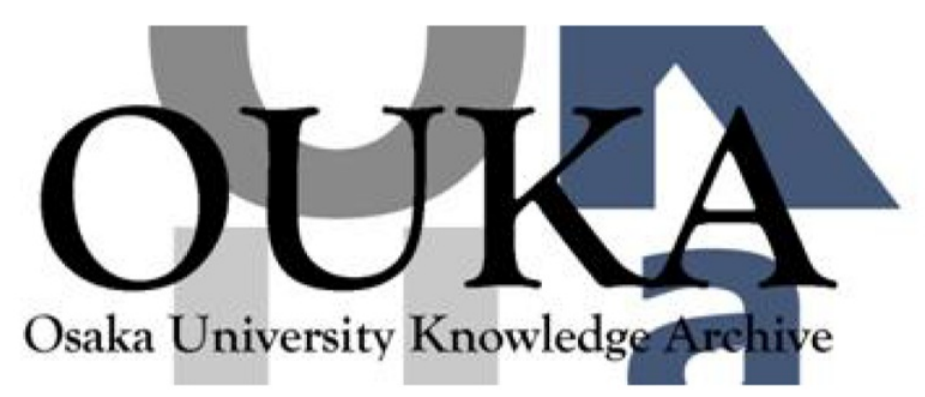

\begin{tabular}{|c|l|}
\hline Title & 再帰を含むプログラムのスライス計算法 \\
\hline Author(s) & 植田，良一; 練，林； 井上，克郎 他 \\
\hline Citation & 電子情報通信学会論文誌D-I. J78-D-I(1) p. 11-p. 22 \\
\hline Issue Date & $1995-01-25$ \\
\hline oaire:version & VoR \\
\hline URL & https://hdl. handle. net/11094/26457 \\
\hline rights & copyright $\odot 1995$ IEICE \\
\hline Note & \\
\hline
\end{tabular}

Osaka University Knowledge Archive : OUKA

https://ir. Library. osaka-u. ac. jp/

Osaka University 


\title{
再帰を含むプログラムのスライス計算法
}

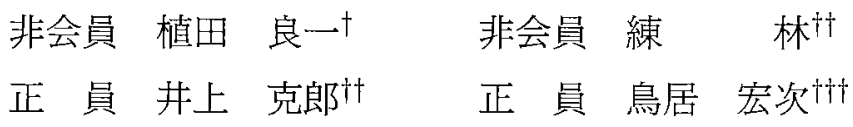

\section{An Algorithm of Computing Slices for Recursive Program}

\author{
Ryoichi $\mathrm{UEDA}^{\dagger}$, Lin $\mathrm{LIAN}^{\dagger \dagger}$, Nonmembers, Katsuro INOUE ${ }^{\dagger \dagger}$ \\ and Koji TORII ${ }^{\dagger \dagger}$, Members
}

\begin{abstract}
あらまし プログラムスライスは，デバッグ，テスト，プログラム合成などに利用される有用な技衔である。 プログラム $P$ のスライスとは，直感的には $P$ 中のある地点 $n$ およびある変数 $v$ に対して， $n$ に扔ける $v$ の值に 影響を与える $P$ 中の各文や式の集合を言う。スライスの計算には，プログラム内の文の間の依存関係の正確な解 析が必要であるが，再帰が存在するプログラムを解析するのは容易ではない．本研究では，再帰を含むプログラ ムの依存関係の静的解析と，その結果基づいてスライスを求めるためのアルゴリズムを提案する. 本アルゴリ ズムでは，再帰的な手続き定義に対応するために，計算に必要な情報をあらかじめ仮定し，その情報をより正し いものへと変化させ，てれが収束するまで解析を繰り返すという方法をとった．更に，手続きの境界を超えてス ライスを計算できるように，独自の改良を施したプログラム依存グラフを定義した。このアルゴリズムは，従来 のものに比べ，再㷌を含むプログラムを効率的に解析することができ，対話的にスライス情報を提供するシスラ ムに組み込むことができる。

キーワード プログラム依存グラフ，到達定義集合，再帰，制御依存関係，データ依存関係
\end{abstract}

\section{1.まえがき}

プログラム $P$ のスライスとは，直感的には $P$ 中の ある地点 $n$ 予よびある変数 $v$ に対して， $n$ に扔ける $v$ の值に影響を与えるP中の各文や式の集合を言う。 すべての可能な入力データに対して解析したものを静 的スライス，特定の入力データに対して解析したもの を動的スライスと言う(本論文では静的スライスのみ を扱うので，以下単にスライスと言えばそれは，静的 スライスを意味するものとする).スライスの技法は Mark Weiser ${ }^{(1)}$ にって提案され，当初はプログラム のデバッグを支援するために使われていたが，現在で は，デバッグだけでなくテストや保守，プログラム合

\footnotetext{
† (株) 日立製作所・システム開発研究所，川崎市 System Development Laboratory, Hitachi, Ltd., Kawasakishi, 215 Japan

† 大阪大学基璴工学部情報工学科, 豊中市 Faculty of Engineering Science, Osaka University, Toyonakashi, 560 Japan

计奈良先端科学技術大学院大学倩報科学研究科, 生駒市

Graduate School of Information Science, Nara Institute of Science and Technology, Ikoma-shi, 630-01 Japan
}

成などにも利用されている(4),(7)，スライスの計算に は，プログラム内の文の間の依存関係の正確な解析が 必要であるが, 再帰が存在するプログラムを正確に解 析するのは容易ではない。

Weiser は，スライスを計算するために，データフ ロー方程式（詳しくは 3.参照）を使ったが，正確な 計算ができるのは一つの手続き内だけだった．Ottenstein $^{(6)}$ が, このスライスの計算をグラフ上の到達可 能性問題に置き換える手法を考案した。この手法を 使って, Horwitz ${ }^{(2),(3)}$ が，手続きの境界を超えてスラ イスが計算できるアルゴリズムを紹介したが，このア ルゴリズムでは各手続き内のデータフロー解析とスラ 亿計算のためのグラフ作成等をいくつかのフェーズ に分けて行うため，効率が覀いものとなっている．ま た，Hwang ${ }^{(5)}$ は，再帰を含むプログラムに対して最 小不動点を求める手法を用いて，スライスを直接計算 する方法を提案したが，一般に，プログラム中の地点 $n$, 变数 $v$ ごとに再帰方程式を解く必要があり，我及 が目指す，対話的にスライス情報を提供するシステム には組み込みにくい. 


$$
\begin{array}{ll}
1 & g:=0 \\
2 & l:=f(5) \\
3 & h:=g+10
\end{array}
$$

図 1 プログラムの一部: $g$ は大域変数で, 関数 $f$ 内で定義 可能

Fig. 1 A part of a program: $g$ is a global variable, so can be redefined in the function $f$.

そこで，本論文では，再帰を含むプログラムの依存 関係の静的解析と，その結果比基づいてスライスを求 めるための，対話的システムに組み込みやすいアルゴ リズムを提案する。我々は，ユーザがさまざまな地点 でのスライスの計算結果を参照したり、部分実行する ような対話的なデバッグ環境でも使劣るようにするこ とを目標にしているので，本アルゴリズムでは，再州 の存在を前提としてソースコードを解析しプログラム 低存グラフを作り，その上でスライスを計算するとい う方法を採用した。

我々のアルゴリズムが対象とする入力言語では，再 帰的に手続きを定義することができる，通常，依存関 係の解析には，データフロー方程式が使われるが，あ る文に手続き呼出しがある場合，陽に現れない変数の 定義や参照が発生し，その影響を知ることが容易では ない.

例えば，図1のようなプログラムを解析するとき， 文 1 で定義された変数 $g$ の内容がそのまま文 3 で使 われる（文 1 の定義が文 3 、纪到達すると言う．正確 には 2.で定義する) 加どうか子性関数 $f$ の内容に依存 する。スライスを計算することを目的とする場合の控 え目な解（無䭾なプログラム断片を含むかもしれない が実行に影響を与えるものすべては必ずスライスとし て残る）は，到達すると考光ることであるが， $f$ を 注意梁く解析すれば，次のような 3 通りに場合分けす ることで，より正確な解を得ることができる.

- $f$ 内で必ず $g$ を定義するとき, 1 は 3 には到 達せず，代わりに， $f$ 内の $g$ の定義が 3 へ到達する

- $f$ が $g$ を定義する場合と定義しない場合の兩 方の可能性があるとき， $f$ 内の $g$ の定義と 1 の両方 が 3 に到達する

・ $f$ が $g$ を定義する可能性が全くないとき，1 が 3 に到達する

また，再帰的な手続き定義を許すことで問題になる のは，再帰的に定義された手続きが，ある実行パス中

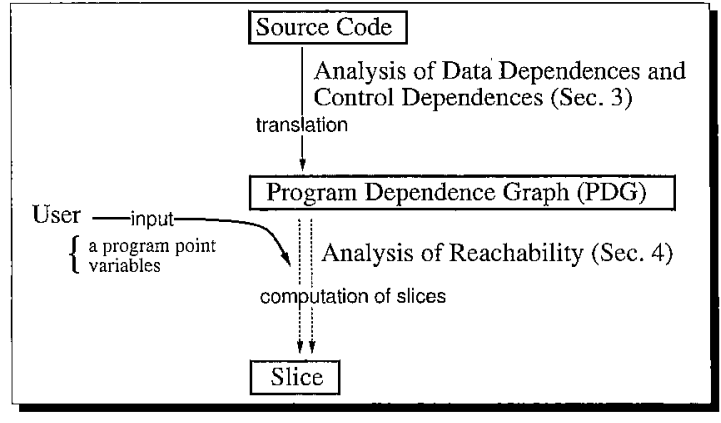

図2 試作システムの全体像

Fig. 2 The overview of our prototype system.

のある文がより前の文へ影響を与える可能性がある， 条件文の条件成立時に実行される文が，不成立時に実 行される文へ影響を与える可能性があるなど，絽返し 文と似た性質をもっていることや，ある手続きの解析 を終劣る前に，その手続きを呼び出す別の手続きを処 理しなければならない場合があることである。

そこで，我々はこれらに対処するために，計算に必 要な情報をあら加じ仮定し，その情報をより正しい ものへと変化させ，それが収束するまで解析を繰り返 すという方法をとった．更に，手続きの境界を超えて スライスを計算できるように，独自の改良を施したプ ログラム依存グラフを定義した。

図 2 にスライスの計算を行うアルゴリズムの概要を 示す.またこのアルゴリズムに従ってプログラムを解 析し，ユーザの入力に応じてスライスを計算し表示す るシステムを試作し，その動作を確認した。

本論文ではこれ以降，2.で，入力言語とプログラ 么依存グラフに関する定義を，3.で，入力プログラ ムからプログラム依存グラフを作る方法（図 2 の細矢 印部分）を，4.で，プログラム依存グラフ上でスラ イスを計算する方法（図2 の破線矢印部分）を，5. で,アルゴリズムの複雑さについて，それぞれ述べる。

\section{2. プログラム依存グラフとスライス}

我々は, Ottenstein, Horwitz と同様に，ソースコー ドを解析しプログラム依存グラフを作り，その上でス ライスを計算するという方法を採用した。この方法は， プログラム依存グラフを作ることにより，はじめの1 回の解析を終えた後は，より少ない時間でスライスを 計算できる（5.参照）もので，対話的にスライス情報 を提供するシステムには適していると考えられる。こ 
の節では，入力言語，プログラム依存グラフおよびそ の上でのスライスを定義する。

\section{1 入力言語}

ここで紹介する解析アルゴリズムの入力言語として， 以下のような特徴をもつPascal風言語を想定してい る.この言語は現実の言語に比べ，簡単化されてはい るが，本質的な構造をすべて含んで扔り，一般の言語 に搪張できる。

その言語には文として条件文 (if), 代入文，繰返し 文 (while), 入力文 (readln), 出力文 (writeln), 手続 き呼出し文，複合文 (begin-end) がある．変数の型と してはスカラ型のみでポインタ型はない.プログラム は，大域変数宣言，手続き（抢よび関数）定義，メイ ンプログラムからなり，ブロック構造はない．手続き 内では, 内部で宣言された局所变数と仮引数変数およ び大域変数のみが参照可能で，他の手続き内の局所変 数は参照できない．手続きは，自己再㷌的および相互 再帰的に定義可能であり，その引数は，值渡しで扱わ 机る。

\section{2 制御依存とデー夕依存}

二つの文の間の関係として制御依存 (Control Dependence，以下 CD) 関係とデー夕依存 (Data Dependence，以下 $\mathrm{DD}$ ) 関係がある。文 $s$ がif文のような条 件判定を含む文であり，かつ， $s$ の条件判定部分 $s_{1}$ の 実行結果が文 $s_{2}$ の実行の有無に值接影響を与えると き， $s_{1}$ と $s_{2}$ の間にCD関係が発生する。これを $\mathrm{CD}$ 関係辺 $\left(s_{1-}-\rightarrow s_{2}\right)$ と表す。市た，文 $s_{1}$ がある変数 $v$ を定義し， $v$ を参照している文 $s_{2}$ にこの定義が到達 するやとき， $s_{1}$ と $s_{2}$ の間に DD 関係が発生する。こ れをDD関係辺 $\left(s_{1} \stackrel{v}{\longrightarrow} s_{2}\right)$ と表す。

\section{3 プログラム依存グラフ (PDG)}

プログラム依存グラフ (Program Dependence Graph，以下PDG) とは，プログラム内の文の間の 依存関係を表す有向グラフであり，その節点は，プロ グラムに含まれる条件判定部分, 代入文, 入出力文, 手続き呼出し文を表し，その有向辺は二つの節点の間 の制御依存および，データ依存関係を表す．但し，手 続きの境界を超えて，スライスを計算できるようにす るために，表 1 に挙げるような，いくつかの特殊節点 も存在する。例宎ば，大域変数 $\mathrm{g}$ と，仮引数 $\mathrm{p}$ をる関 数 $f$ をもつプログラムには図 3 にあるように， exit 節点 $f-e x i t$, in 節点 $f_{g}-i n$, out 節点 $f_{g}-o u t$, 引数節点 $f_{p}-$ parが存在する。

このように、我々のアルゴリズムでは Horwitzの方

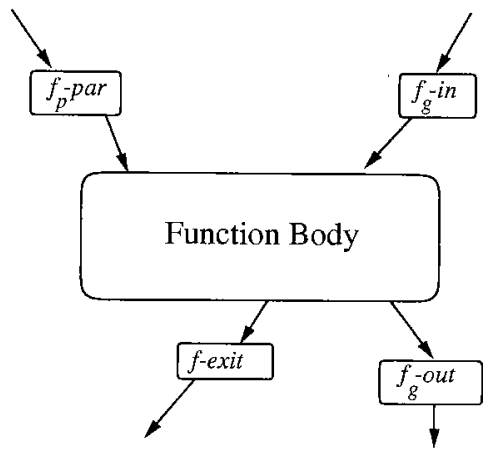

図 3 関数 $f$ 䇃素るPDGの概略

Fig. 3 The outline of PDG for a function $f$

表 1 特殊節点

\begin{tabular}{|c|c|c|}
\hline & 特殊節点 & 表記例 \\
\hline exit 節点 & $\begin{array}{l}\text { 関数の戻り值を通して伝わる影響を検 } \\
\text { 出するための節点で, 各関数につつず } \\
\text { つある }\end{array}$ & $f$-exit \\
\hline in 節点 & $\begin{array}{l}\text { 手続き外からの大域変数の影響を内部 } \\
\text { へ伝えるための節点で, 手続きに, 個々 } \\
\text { の大域変数に対して, 一つずつある }\end{array}$ & $f_{g}-\hat{i n}$ \\
\hline out節点 & $\begin{array}{l}\text { 手続き内で定義された大域変数の影響 } \\
\text { をの外へ伝えるための䬣点で, 手続 } \\
\text { きに, 個々の大域変数に対して, 一つ } \\
\text { ずつある }\end{array}$ & $f_{g}-o u t$ \\
\hline 引数節点 & $\begin{array}{l}\text { 手続きの引数を通して伝わる影響を検 } \\
\text { 出するための節点で, その引数それぞ } \\
\text { れに一つずつある }\end{array}$ & $f_{p}-p a r$ \\
\hline
\end{tabular}

法と同様に、プログラムには現れない特殊節点を使っ て手続き間のデータフローを検出する。

\section{4 スライス}

プログラムをPDGで表現し，「文 $s に$ にるる変数 $v$ に関するスライスとは，PDG上でCD関係辺または $\mathrm{DD}$ 関係辺をたどって文 $s$ の変数 $v$ に到達できる百節点 集合に対応する文の集合である」と定義する。

例えば，図4のプログラムの文 writeln(c) に関 するスライスは，図 5 のようになり，この部分を゙けを 実行しても指定した文でのcの值は同じものになる。

\section{3. $\mathrm{PDG}$ への変換}

ソースコードをPDGに変換するには，プログラム 中の各文の間の $\mathrm{CD}$ 関係および $\mathrm{DD}$ 関係を知る必要が ある。CD関係は入力言語仕様より容易に求めること ができるので，ここでは，DD関係の求め方を詳しく

$\dagger r_{s_{1}}$ から $s_{2}$ への，vの再定義を含まないような実行パスが存在す る」と同義。 


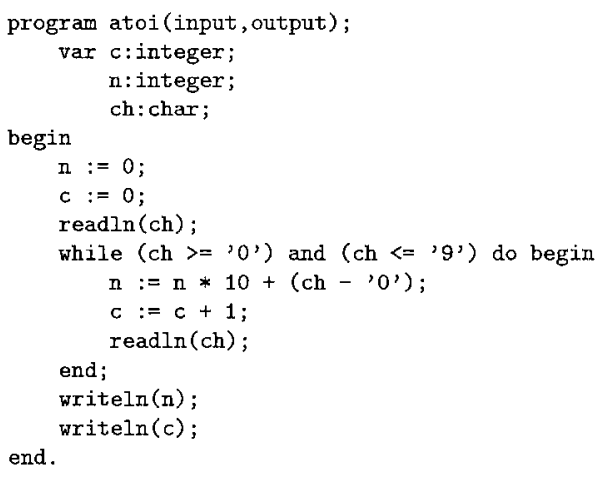

図4 プログラムatoi:入力文字列を整数に变撸してその数とけた

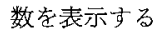

Fig. 4 Program atoi: converts an input string to the corresponding integer and displays its integer and its number of places.

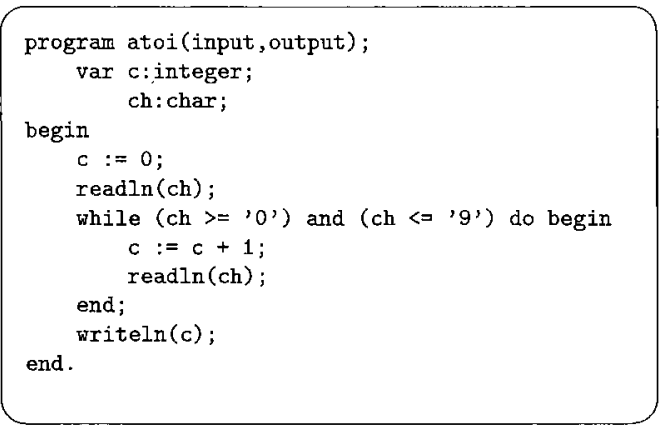

図5 atoiの文writeln(c) に関するスライス:けた数を表示す る部分加抽出与れている

Fig. 5 The slice at the statement writeln (c): the only part which calculates the number of places is extracted.

説明する。

\section{1 諸 定 義}

変数 $v$ と節点 $n$ との組 $d$ を $\langle v, n\rangle$ と表し, 变数部を $d_{v a r}$ で，節点部を $d_{\text {vertex }}$ で表す. プログラムの施る 領域 $S$ (連続する0 個以上の文の集合)に対する到達定 義集合 (Reaching Definition Set) $R D_{i n}(S)$ を，次の ように定義する。

$$
\begin{array}{r}
R D_{\text {in }}(S) \equiv\{\langle v, n\rangle \mid \text { 節点 } n \text { で変数 } v \text { が定義さ } \\
\text { れる } \wedge n \text { が } S \text { の先頭へ到達する }\}
\end{array}
$$

また，Sを出て次の領域へ到達する定義集合を $R D_{\text {out }}(S)$ と書く. 一般に式(1)のような関係が成り
立つ. 但し， $\operatorname{kill}(S)$ は $S$ で消滅する†定義の集合を, $\operatorname{gen}(S)$ 活 $S$ で新たに発生する定義の集合を意味する。

$$
R D_{\text {out }}(S)=\left(R D_{i n}(S)-k i l l(S)\right) \cup \operatorname{gen}(S)(1)
$$

プログラムのある領域 $S$ につて，S を実行したと きに(どのパスが寒行されても)必ずその值が定義され る変数とその定義節点との組の集合を確実定義集合と 呼び， $S u D E F(S)$ と表す．また，定義される可能性 のある変数とその定義節点との組の集合を潜在定義集 合と呼び，PoDEF $(S)$ と表す．定義より，二つの定 義集合間には次の上うな関係がある。

$$
\operatorname{SuDEF}(S) \subseteq \operatorname{PoDEF}(S)
$$

更に，次のように定義する。

$$
\begin{aligned}
& S u D E F_{v a r}(S) \equiv\left\{d_{v a r} \mid d \in \operatorname{SuDEF}(S)\right\} \\
& \operatorname{PoDEF}_{\text {var }}(S) \equiv\left\{d_{\text {var }} \mid d \in \operatorname{PoDEF}(S)\right\}
\end{aligned}
$$

この確実定義集合と潜在定義集合を使うと，式 (1) は 次のように書き換えることができる.

$$
\begin{aligned}
R D_{\text {out }}(S)= & \left(R D_{\text {in }}(S)-\{\langle v, n\rangle \mid v\right. \\
& \left.\left.\in S u D E F_{\text {var }}(S)\right\}\right) \\
& \cup \operatorname{PoDEF}(S)
\end{aligned}
$$

また，次に示す条件をすべて満たす変数 $v$ を「手 続き $p$ で暗使用される変数」と呼び，その集合を $\operatorname{ImUSE}(p)$ と表す.

- $v$ 注大域変数である

- $p$ 内での $v$ の参照地点に $p$ 外の $v$ の定義が到達 する

$\operatorname{ImUSE}(p)$ に含まれる変数は手続き $p$ の呼出し地点 $s$ には直接現れないが， $p$ の呼出しによって参照され ると解釉して， $R D_{i n}(s)$ に含まれる定義節点加ら $s$ 亿 のDD関係を作るために使われる。

\section{2 プログラム全体の解析}

プログラムは手続きを一つの単位として解析される。 手続き $p$ の解析には $p$ 自身の構造に関する情報以外に $p$ が直接呵び出す手続き $q$ の確実定義集合 $(S u D E F(q))$, 潜在定義集合 $(P o D E F(q))$, 暗使用される変数集合 ( ImUSE $(q))$ 几関する情報が必要となる。しかし， 再帰を含むプログラムを解析する際には，q 解析す る前に $q$ を呼び出す別の手続き $p$ を解析しなければ ならない状況が起こり得る。よって，手続きの解析を 開始する前にすすべての手続きに対して，そのSUDEF，

$\dagger S$ 以降の文比到達しない。 
PoDEF, ImUSE の初期值を与える必要がある。

手続き $r$ が別の手続き $s$ を呼び出すが， $s$ は $r$ を呼 び出さないとき，rの定義集合は $s$ の定義集合に依存 するので， $s$ の解析の後に，rの解析をする方が，rの 定義集合が早く収束することは明らかである．このよ うに，手続き間の呼出し関係学解析し，手続きの解析 順序をうまく選ぶことにより，手続きの総解析回数を 少なくできる。

解析順序を決定するためには，手続き間の「呼ぶ一 呼活れる」関係学知る必要があるので, 入力プログラ ムに対して，手続き名を節点で，また，「呼ぶ一呼ば れる」関係を，呼ぶ側から呼ばれる側への有向辺で 表した呼出しグラフ (Call Graph, 以下 CG)を作る. あるプログラムのCGが有向無閉路グラフ (Directed Acyclic Graph，以下DAG)になるとき，そのプログ ラムには，相互/自己再帰呼出しがない.

手続きが再帰的に定義されているとき，その解析に 使われる情報が不正確な場合があり，通常，その手続 きを一度解析しただけでは，その定義集合は収束して いない、そこで, 関連する再帰呼出しを含す手続き集 合を，その他の手続き集合と分離して，それぞれの手 続きの定義集合が収束するまで，その集合内の手続き のみを解析し続け西。

関連する再帰呼出しを含む手続き集合は，直接また は間接的に相互に呼び出す可能性のある手続きの集 合であるから，CG上では強連結成分 (Strongly Connected Component)として現れる。再帰呼出しを含 まない手続きは，その手続き一つたけからなる強連結 成分として抽出される. CG上での強連結成分の抽出 方法については文献 (8) の10章を参照されたい。

次に，強連結成分間の解析順序を決めなければなら ない. 強連結成分を一つの節点として, 強連結成分 間をつなぐCG上の辺のみをその辺としてもつ縮約グ ラフ (Reduced Graph) CG'を作ると，これは強連結 成分の定義から DAGになる， $\mathrm{CG}^{\prime}$ 内の辺は，強連結 成分間の「㭔ら゙一呼ばれる」関係を表しているので, $\mathrm{CG}^{\prime}$ 上をその根加梁さ優先探索をして，ポストオー ダで順序付けすれば，これが强連結成分間の最適な解 析順序になる。

以上をまとめると，次のようになる。

アルゴリズム ANALYZEPROGRAM

Input: プログラム $P$

Output: $P$ ФDG
Step 1. プログラムP のCG_上で強連結成分を抽出 して，その縮約グラフを作り，その根から深さ優先探 索して，ポストオーダで順序付けする（但し，1回の 探索ですべての節点に到達できないとき(グラフが連 結でないとき)は，末到達の節点がなくなるまで繰り 返しすべての節点を順序付けする).

Step 2. 各強連結成分内の要素任意の要素から深导 優先探索して，ポストオーダで順序付けする

Step 3. 各手続きの SuDEF, PoDEF, ImUSE を以下のよ うに初期化する(但し, 変数 $S u D E F(f)$ は手続き $f$ 全体化対する確実定義集合を意味する).

$$
\begin{aligned}
& S u D E F(f) \leftarrow \phi \\
& P o D E F(f) \leftarrow \phi \\
& \operatorname{Im} U S E(f) \leftarrow \phi
\end{aligned}
$$

Step 4. Step 1 で決定した順序で強連結成分 $S$ を一 つずつ選び以下の手順で解析する

(a) S内の各手続きを Step 2 で決定した順序 で1回ずつアルゴリズムANALYZEPROCEDUREを使っ て解析する（アルゴリズムANALYZEPROCEDURE は 3. 3. で説明する)。

(b) $S$ 内のす心゙ての手続きのSUDEF，PoDEF， ImUSEが変化しなくなるまで(a) を繰り返す†.

Step 5. メインプログラムを解析する

\section{3 一つの手続きの処理}

一つの関数 $f$ は, 一般に図6 のような構造で表さ れる.ここではその本体の領域を $B$ とする。この $f$ は 以下の手順で解析される（手続きの場合，関数と違っ て戻り值がなく， exit節点が不要なので，この節点に 関する辺を作らないところを除けば関数の場合と同じ である)。

\section{アルゴリズム ANALYZEPROCEDURE}

Input: 手続き $f$.(その本体の領域を $B$ とする)

Output: $\quad S u D E F(f), \operatorname{PoDEF}(f), \operatorname{ImUSE}(f)$ の変化の有無

Step 1. $R D_{i n}(B) \leftarrow\left\{\left\langle u, f_{u}-p a r\right\rangle \mid u\right.$ は $f$ の仮引数 変数 $\} \cup\left\{\left\langle v, f_{v}-i n\right\rangle \mid v\right.$ 江大域変数 $\}$

†但し, $S$ が再帰呼出しを含まない手続きつつだけからなるときは, 繰り返し解析してもその手続きのSuDEF, PoDEF, ImUSE 虫变 化しないので，その手続きを1回解析するだけでSの解析定終える。 


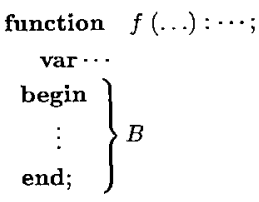

図6 関数定義の概略

Fig. 6 The outline of a function definition.

表 2 各文での確実定義集合の計算方法

\begin{tabular}{|c|c|}
\hline & 各文の確実定義集合 \\
\hline 代入文 & 左辺の変数が確奏定義集合に入る \\
\hline 条件文 & $\begin{array}{l}\text { then 節と else節それぞれの確実定義集合 } \\
\text { の積集合が文全体の確実定義集合となる }\end{array}$ \\
\hline 絽返し文 & $\begin{array}{l}\text { 確実定義はない(繰返し本体が一度も実行 } \\
\text { されない可能性のある前判定型であるた } \\
\text { め) }\end{array}$ \\
\hline 複合文 & $\begin{array}{l}\text { 各文の確実定義集合の和集合が全体の確実 } \\
\text { 定義集合となる }\end{array}$ \\
\hline 手続き呼出し文 & $\begin{array}{l}\text { 呼び出される手続きの確実定義集合が文全 } \\
\text { 体の確実定義集合となる }\end{array}$ \\
\hline 入力文 & $\begin{array}{l}\text { 入力值を代入される変数が確実定義集合に } \\
\text { 入る }\end{array}$ \\
\hline 出力文 & 確実定義はない \\
\hline
\end{tabular}

表 3 各文での潜在定義集合の計算方法

\begin{tabular}{ll}
\hline & 各文の潜在定義集合 \\
\hline 代入文 & 左辺の変数が潜在定義集合に入る \\
条件文 & then節と else節それぞれの潜在定義集合 \\
& の和集合が文全体の潜在定義集合となる \\
繰返し文 & 条件成立時に実行される文の潜在定義集合 \\
& が全体の潜在定義集合となる \\
複合文 & 各文の潜在定義集合の和集合が全体の潜在 \\
& 定義集合となる \\
手続き呼出し文 & 呼び出される手続きの潜在定義集合が文全 \\
& 体の潜在定義集合となる \\
入力文 & 入力值を代入される変数が潜在定義集合に \\
& 入る \\
出力文 & 潜在定義はない
\end{tabular}

但し，複合文において，同じ変数に対する定義がある場合，より後の 定義が全体の定義集合に含まれる(式 (2) 参照)。中た，文が含す式に関 数呼び出しがあるとき, 呼び出される関数の定義集合をその文の定義第 合に加える.また，时び出される関数で暗使用される変数がその文で参 照されたようにDD関係辺をつなぐ。

Step 2. $B$ 内の文を表 2 , 表 3 に基づいて解析する. これによって， $f$ 内のCD関係辺，DD関係辺が作 られ, $R D_{\text {out }}(B), \operatorname{SuDEF}(B), \operatorname{PoDEF}(B)$, $\operatorname{ImUSE}(B)$ の值が計算される(但し, $\operatorname{ImUSE}(B)$ は $f$ が呼び出す手続きの現在のImUSEの值を使って計 算し直した結果を意味する)。
Step 3. 次のようにして, 各変数の変化を調心゙る（但 し, Global は変数集合の中の大域変数だけを選ぶこ とを意味する)。

$$
\begin{aligned}
\operatorname{SuDEF} F_{\text {var }}(f) & ==\operatorname{Global}\left(\operatorname{SuDEF} F_{\text {var }}(B)\right) \\
\operatorname{PoDEF} F_{\text {var }}(f) & ==\operatorname{Global}\left(\operatorname{PoDEF} F_{\text {var }}(B)\right) \\
\operatorname{ImUSE}(f) & ==\operatorname{ImUSE}(B)
\end{aligned}
$$

左辺の各変数は，初期值として与えたもの，または， この解析が 2 度目かそれ以降のときは, 前回の解析時 に代入されたものである。これらのうち,一つでも変 化したものがあるときは，次の操作をして定義集合が 変化したこと学記録しておく。

$$
\begin{aligned}
& S u D E F(f) \leftarrow\left\{\left\langle v, f_{v}-o u t\right\rangle\right. \\
& \left.v \in \operatorname{Global}\left(\operatorname{SuDEF} F_{v a r}(B)\right)\right\} \\
& \operatorname{PoDEF}(f) \leftarrow\left\{\left\langle u ; f_{u}-\text { out }\right\rangle \mid\right. \\
& \left.u \in G \text { Gobal }\left(\operatorname{PoDE} F_{\text {var }}(B)\right)\right\} \\
& \operatorname{Im} U S E(f) \leftarrow \operatorname{Im} U S E(B)
\end{aligned}
$$

Step 4. $R D_{\text {out }}(B)$ の中から, 関数の戻り值に関す る定義を探し，その定義節点 $n$ から exit節点への DD 関係辺 $(n \stackrel{f}{\longrightarrow} f$-exit $)$ を作る。また，同様に，各大 域変数 $g$ に関する定義を探し, その定義節点 $m$ から, out節点へのDD関係辺 $\left(m \stackrel{g}{\longrightarrow} f_{g}-o u t\right)$ を作る.

\section{4 解 析 例}

ここでは，3.2.で示したアルゴリズムANALYZEPROGRAMを使って，図 7 の左のプログラムを 解析する様子を示す。

はじめに, Step 1 でプログラム progressionの CG を作り, 強連結成分を抽出すると（図 8), 手続きの解 析順として, $\{f\} \Rightarrow\{n t h\}$ が得られる。次に, Step 2 を行い，Step 3 で各変数に初期值を代入する。その 後, Step 1 で得られた解析順に従って, Step 4(a) で $\{f\}$ 内の手続き $f$ をANALYZEPROCEDUREを使っ て解析するとその本体 $B$ での定義集合が次のように なる.

$$
\begin{aligned}
S u D E F_{v a r}(B) & =\{f, g\} \\
P o D E F_{v a r}(B) & =\{f, g, l\} \\
\operatorname{Im} U S E(B) & =\phi
\end{aligned}
$$

†より詳しくは，文献(9)を参照されたい。 


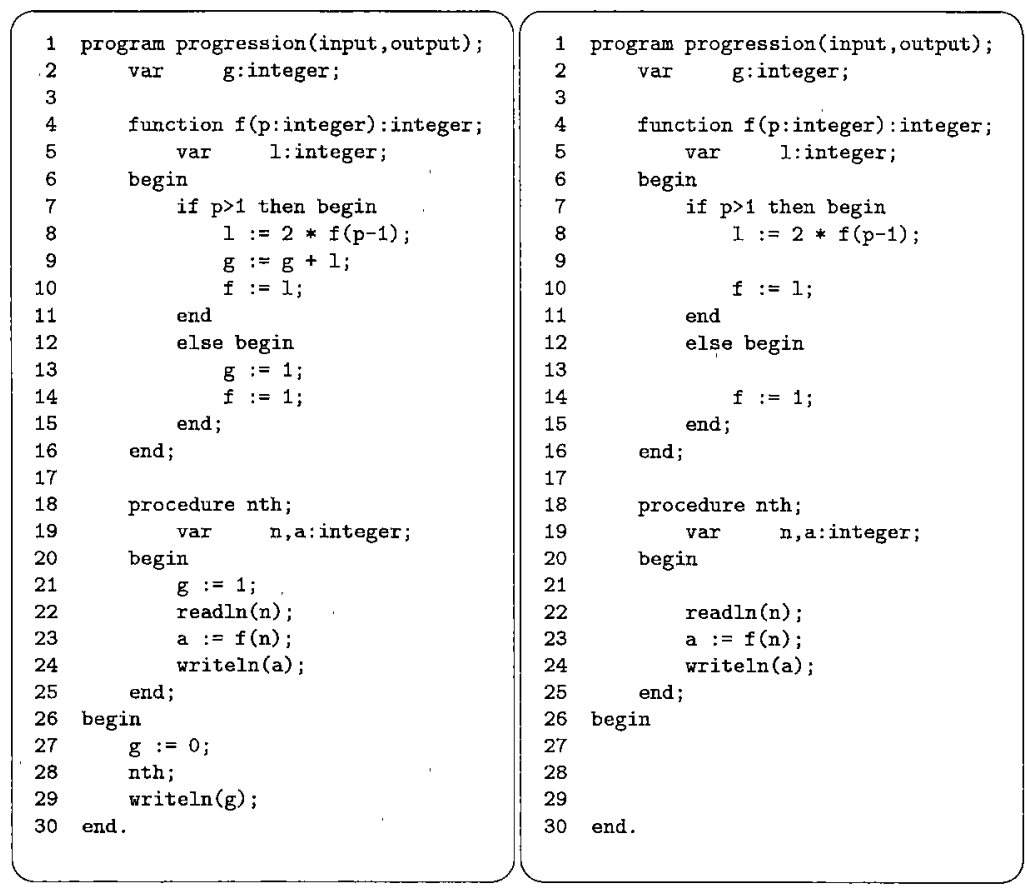

図 7 スライスの計算例

Fig. 7 An example of calculating a slice.

$f$ は大域変数 $\mathrm{g}$ を文 $9 て ゙$ 参照するが，この参照の 前に文 8 の手続き呼出しで，gを必ず定義するの で, $\operatorname{ImUSE}(B) \mathrm{gg}$ は含まれない。このとき， $S u D E F_{\text {var }}(B)$ と PoDEF $F_{\text {var }}(B)$ の値は初期値加 ら変化しているので, 各変数の值は以下のように更 新され，Step 4(b)によって再度 $\{f\}$ に対して Step 4(a)が実行される.

$$
\begin{aligned}
& \text { SuDEF }(f) \leftarrow\left\{\left\langle g, f_{g}-o u t\right\rangle\right\} \\
& \text { PoDEF }(f) \leftarrow\left\{\left\langle g, f_{g}-o u t\right\rangle\right\} \\
& \operatorname{ImUSE}(f) \leftarrow \phi
\end{aligned}
$$

$(\{f\}$ は一つの要素しかもたないが，その手続き $f$ が 再帰呼出しを含むので再度解析しなければならない.)

2 回目の $\{f\}$ の解析では定義集合が変化しないので $\{f\}$ の解析が終る. 次に Step 4(a)により, $\{n t h\}$ の 解析をする. $\{n t h\}$ の 1 回目の解析により，その定義 集合は次のように更新される.

$$
\begin{aligned}
& S u D E F(n t h) \leftarrow\left\{\left\langle g, n t h_{g}-o u t\right\rangle\right\} \\
& P o D E F(n t h) \leftarrow\left\{\left\langle g, n t h_{g}-o u t\right\rangle\right\} \\
& \operatorname{ImUSE}(f) \leftarrow \phi
\end{aligned}
$$
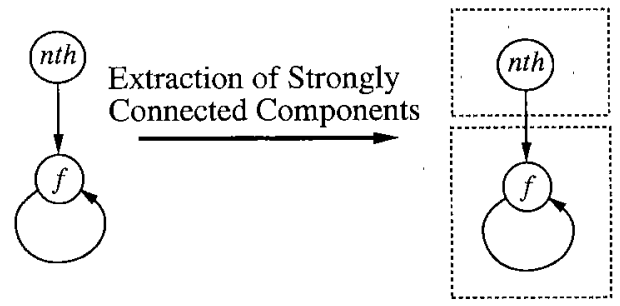

図 8 プログラムprogression に対するCG

Fig. 8 The call graph for the program progression.

$\{n t h\}$ は再㷌呼出しを含まない手続き一つからなる強 連結成分なので解析を繰り返してもその定義集合は変 化しない.よって，\{nth\}の解析は 1 回で終わる.

最後に, Step 5でメインプログラムを解析してプ ログラム全体の解析を終える。

\section{4. スライスの計算}

この章では PDG上でスライスを計算する方法を示 す（図2 の破線矢印部分）。本アルゴリズムでは,「文 $s$ における変数 $v$ に関するスライスとは, PDG上で $\mathrm{CD}$ 関係辺またはDD関係辺をたどって文 $s$ の変数 $v$ に到達できる節点集合に対応する文の集合である」と 
定義したので，PDG上でのスライスの計算は節点間 の到達可能性の判定と同じである。但し, 我々が定義 したPDGには手続きの境界を超えてスライスを計算 できるようにいくつかの拡張がなされているので，た どることのできる辺に制限が付く．

プログラム内の文 $s$ での変数 $v$ に関するスライスを 表す節点の集合 $V$ は，以下に示すような手順で計算で きる．但し， $n_{s}$ は $s$ に対応する節点である。

\section{アルゴリズム GeTSLICEONPDG}

Input: PDG, 文 $s$, 変数 $v$

Output: スライスを表す節点の集合 $V$

Step 1. $V \leftarrow\left\{n_{s}\right\}$

Step 2. $N \leftarrow\left\{n \mid n \stackrel{v}{\longrightarrow} n_{s}\right\}^{\dagger} \cup\left\{m \mid m--\rightarrow n_{s}\right\}$

Step 3. $N \neq \phi$ の間，以下の操作を繰り返す

(a) $n \in N$ を一つ選ぶ

(b) $N \leftarrow N-\{n\}$

(c) $V \leftarrow V \cup\{n\}$

(d) $n$ が in 節点でも引数節点でもないなら次の操 作をする

$N \leftarrow N \cup\{m \mid m \notin V \wedge(m \longrightarrow n \vee m--\rightarrow n)\}$

(但し $m \longrightarrow n$ は $m$ から $n$ への任意の変数の

$\mathrm{DD}$ 関係辺を表す)

スライスを計算する対象を文 $s$ 全体にするには Step 2 を次のように変更すればよい.

Step 2'. $\quad N \leftarrow V$

また，文の集合 $S$ に対するスライスを計算するとき は，更に，Step 1を次のように変更すればよい。

Step 1'. $\quad V \leftarrow \bigcup_{s_{i} \in S}\left(s_{i}\right.$ を表す節点 $)$

節点とプログラムの断片は 1 対 1 に対応しているの で，Vが求まると，それに対応したプログラムを作り 上げることは簡単である。例えば，図 9 のPD上で 文writeln (a)での変数aについてのスライスを計算 した結果が図 9 中の破線四角形で示された節点であ り，この節点集合に対応するソースコードの部分を集 めたものが図7 の右のプログラムとなる。

\section{5. アルゴリズムの複雑さ}

この章では 3.，4.で紹介したアルゴリズムの複雑さ について述べる。我々のアルゴリズムは，ソースコー ドをPDG に変換する部分 (ANALYZEPROGRAM) と,
PDG上でスライスを計算する部分 (GETSLICEONPDG) とに分けられるので, 複雑さについても両者安 分けて考光る。

\subsection{PDG を作るコスト}

ソースコードから PDGを作るための解析にかかわ る要素を以下の表のように定義する。

\begin{tabular}{ll}
\hline & $\mathrm{PDG}$ 作成にかかわる要素 \\
\hline$P$ & 手続きの総数 \\
$G$ & 大域変数の総数 \\
$L$ & 手続きの局所変数の数の最大值 \\
$S_{i}$ & 手続き呼出しの総数 \\
$S_{t}$ & 文の総数 \\
\hline
\end{tabular}

[補題 1] プログラム中の寸べての手続きが再州呼 出しを含むときが解析に最も時間がかかる。

(証明)すべての手続きを少なくとも1回は解析しな ければならないことは明らかである。再帰呼出しを含 まない手続きは，その手続き一つだけからなる強連結 成分に含まれる。この強連結成分の解析はそれが含む 手続きを 1 回解析するだけで終わるので，このような 手続きが存在しないときに，すなわち，プログラム中 のすざての手続きが再帰呼出しを含むときに，プログ ラム全体の解析に最も時間がかかる。

[補題 2] 手続きのSUDEF, PoDEF, ImUSEに含まれる 要素は, 解析の繰返しによって単調に増加する。 (証明) 手続き $p$ 内での, 手続き呼出しによらない直 接的な，確実定義集合を $S_{d}$ とすると， $S u D E F(p)$ は $S_{d}$ と $p$ が直接呼び出す別の手続きのSUDEFだけを 変数としてもつ，否定を含まない積と和だけからなる 論理式で表現される。この論理式と $S_{d}$ の值はプログ ラムが変化しない限り変化せず，各手続きのSuDEFは 最小（空集合）に初期化されるので，SuDEF(p)に 含まれる要素は単調に増加する。

同様のことが $\operatorname{PoDEF}(p)$ と ImUSE $(p)$ について も言えるので，これらに含まれる要素も単調に増加 する。

[補題 3] アルゴリズムANALYZEPROGRAMでは一 つの強連結成分 $S$ に含まれる手続きの解析（Step 4(a)）の繰返しはたかだか $|S|$ 回で終わる（但し， $|S|$

†ょり正確には $\left\{n \mid\langle v, n\rangle \in R D_{i n}(s)\right\}$ であるが，一般に，コーザ は变数 のの参照を含む文を $s$ に指定する場合が多いのでここでは， このわかりやすい表現を用いた。 


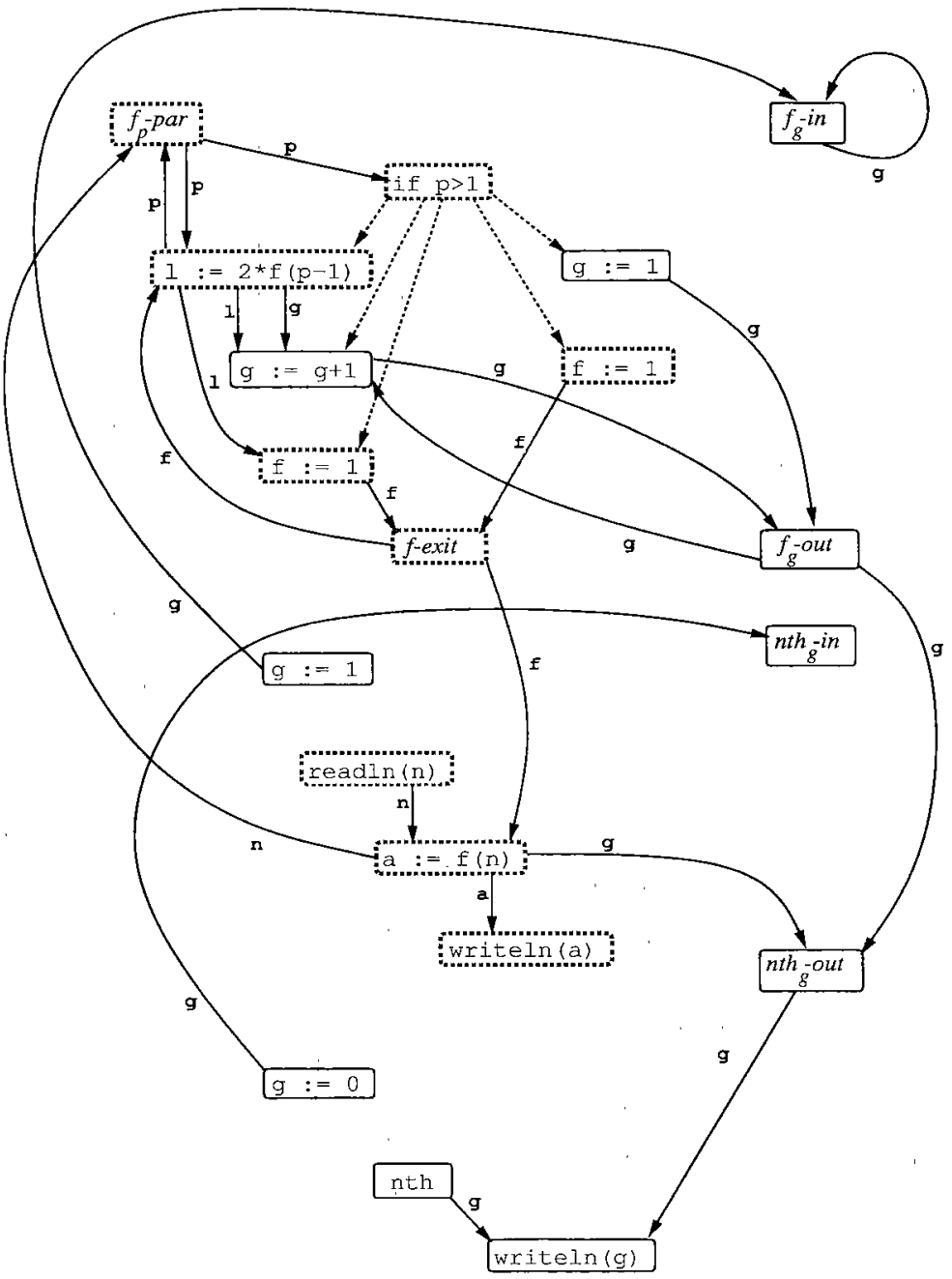

図9プログラムprogressionに対するPDG: 破線四角形は文 writeln (a)での変数a関するスライスを計算したときの節点 集合に含まれる節点である

Fig. 9 The PDG for the program progression; vertices enclosed with a dashed rectangle means a slice with respect to the statement writeln (a) and the variable $a$.

はSに含まれる手続きの数を表す)。

(証明) 強連結成分 $S$ に含まれる手続き $p^{\prime}$ の $S U D E F_{\text {var }}(p)$ に大域変数 $\mathrm{g}$ が含まれていることを $g_{p}=$ trueで，含まれていないことを $g_{p}=$ falseで表 現する。

$S u D E F(p)$ は，手続き $p$ 内での，手続き呼出しに よらない直接的な，確実定義集合と $p$ が直接呼び出す 別の手続きのSUDEF だけを変数としてもつ，積と和だ けからなる論理式で表現される。
我久の入力言語仕様では別名 (Alias) が発生しない ので，どの大域変数も互いに影響を及ぼすことはない。

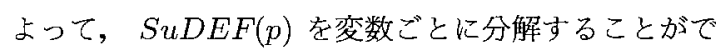
き, $g_{p}$ は $p$ が直接呼び出す手続き $q_{1}, q_{2}, \ldots$ に関する $g_{q_{1}}, g_{q_{2}}, \ldots$ を変数としてもつ, 積と和だけからなる 論理式で表現される。この $g_{q_{1}}, g_{q_{2}}, \ldots$ のうち，Sに 含まれない手続き记関するものは既に值が決定してお り,変化することはない。 
また, 補題 2 より, ある $g_{p}$ が初期值 false からいつ たんtrue に変化すると再びfalse に変化することは ない。

$S$ 全体を1回解析して，Sに含まれる手続き $p$ の どの $g_{p}$ も変化しなけ机ば，その後の解析で変化する ことはないので， $S$ 全体を1回解析するごとに $S$ に含 まれる一つの手続き $p$ の $g_{p}$ にだけ変化が起こるとき, $S$ の解析の回数が最大となる.これは, SuDEFだけで なく,PoDEF, ImUSE に対しても同様である。これは ANALYZEPROGRAM が停止することと同時に，Sに含 まれる手続きの解析はたかだか $|S|$ 回で終わることを 示している.

[定理 1] アルゴリズムANALYZEPROGRAMの時間 計算量は $O\left(P+S_{i}+P \cdot S_{t} \cdot(G+L)\right)$ である. (証明) アルゴリズムANALYZEPROGRAM の Step 1, Step 2 に要する時間はプログラムのCGの節点と有向 辺の数の和に比例する. 節点の数は $P$ で, 有向辺の数 は $S_{i}$ で，それぞれ抑えられる. Step 3 は手続きの数 に比例する時間で終わる。

ANALYZEPROGRAMの繰返し部分Step 4(a) は, 補 題 $1 ， 3$ より,プログラム中のすべての手続きが一つ の強連結成分に含まれているとき, 最も時間がかかる。 このとき,プログラム中のすべての手続きが最大 $P$ 回 ずつ解析される.

プログラム中のすべての手続きを1回ずつ解析する， すなわち，プログラム中のすべての文を1回解析する のに要する時間は, 文の数に比例する。一つの文の解 析には定数回の集合演算が必要である.1回の集合演 算にかかる時間が集合に含まれる要素の数に比例する と仮定すると，一つの文の解析の時間は大域変数と局 所変数の数の和に比例する.

故に,アルゴリズムANALYZEPROGRAM の時間計 算量は $O\left(P+S_{i}+P \cdot S_{t} \cdot(G+L)\right)$ である.

\subsection{PDG 上でスライスを計算するコスト}

PDGにかかわる要素を以下のように定義する。

\begin{tabular}{l}
\hline PDG上でのスライスの計算に関わる要素 \\
\hline$V \quad \mathrm{PDG}$ 節点の総数 \\
$E \quad \mathrm{PDG}$ 有向辺の総数 \\
\hline
\end{tabular}

アルゴリズムGETSLICEONPDGでは，PDG上で スライスを計算する際, すべての節点とすべての有向 辺を多くとも1回しかたどらないので，そのコストは $O(V+E)$ である.

\section{3 解析全体にかかるコスト}

ソースコードから始めてスライスを計算するまでに $O\left(P+S_{i}+P \cdot S_{t} \cdot(G+L)+V+E\right)$ の時間がかか るが，その後ソースコードに変更がなければ， $O(V+$ E) の時間でスライスの再計算ができる.

但し，これはプログラム中のすべての手続きが互い に呼び合う可能性がある場合で，このようなプログ ラムは，非常にまれにしか存在しないと考无られる。 よって，一般的なプログラムに対しては， $O\left(P+S_{i}+\right.$ $\left.S_{t} \cdot(G+L)+V+E\right)$ の時間でスライスの計算がで きる。

\section{6. むすび}

本論文では，再㷌を含むプログラムにおいて，文の 間の依存関係を解析し, プログラムをPDGに変換し, その上でのスライスを計算するアルゴリズムを紹介し た. 本アルゴリズムは, 実際の解析が行われる前に, 控え目な解を初期值として定義しておき，必要に応じ て解析を繰り返して真の解に収束させるというもので, 再兴を含むプログラムの解析には適したものであると 思われる。

我々のアルゴリズムはWeiserのものと比べ，手続き 間のスライス計算をより正確に行うことができる点, および，再帰を取り扱える点で有利である。例元ば， 図 7 のブログラムの文 $21 や 27$ は文 29 での変数 $\mathrm{g}$ の值 には影響を及添していないにもかかわらず，Weiserの アルゴリズムでは及汇していると解釈されスライスに 含められる。

再帰を含むプログラムのスライスを計算するアルゴ リズムは, ほかに, Hwangによるもの ${ }^{(5)}$ と Horwitz によるもの ${ }^{(3)}$ がある．前者のアルゴリズムは，再州呼 出しの深さごとに, スライスを計算し, それらの和集 合が収束するまでその計算をするというもので，PDG を作らない.よって，プログラムを解析してPDGで表 し，その上でスライスを計算する我々のアルゴリズム に比べると，スライスを何度も計算するときに非常に 不利になり，実際のデバッグ環境を考えると満足でき るものであるとは言いがたい.また，ソースコードの 変更の影響が及ぶ箇所を知るためなどに使われる順方 向スライス (Forward Slice)を計算するために, PDG をそのまま使うことができる点でも我々のアルゴリズ ムは有利である。

後者のアルゴリズムに比べると, 我々のアルゴリズム では, プログラム内の各文の到達定義集合を計算して 
いるので，プログラムの任意の地点の任意の変数に対す るスライスが計算できる点，抢よび，ソースコードが変 更されたときに，再解析が必要になる部分をより少なく でき，インクリメンタルにPDGを更新する方法をとる ことができる点で有利であると考劣られる。更に，時間 計算量を比較すると，Horwitzによるものが $P_{r}$ を仮引 数の数の最大值, $D \leqq\left(S_{t}+1\right) \cdot\left(G+P_{r}\right)$ としたとき, $O\left(\left(P+S_{i}\right) \cdot D^{2} \cdot\left(G+P_{r}\right)^{2}\right)$ であるのに対して, 我及 のアルゴリズムでは $O\left(P+S_{i}+P \cdot S_{t} \cdot(G+L)\right)$ で ある。

また，関連するアルゴリズムとしては，Harroldら の「定義一参照」関係の計算法がある ${ }^{(12)}$.この方法で は，手続きにまたがるDD関係を正確に解析すること ができるが，3.2.で述べるような関数間の解析順を考 慮していないため, 通常, 手続き間の解析情報の伝搬 に多くの時間を要する。また，Pandeらはある種のポ インタを含むCプログラムの関数間にまたがる「定義一 参照」関係を求めるアルゴリズムを提案している ${ }^{(13)}$. 我及は，本アルゴリズムに従ってスライスを計算し， 表示する試作システムを作成し，本アルゴリズムが正 しく動作することを確認したこのシステムはSUN SPARCstation ELC上で動作し，13個の手続き，7個 の大域変数を含む再帰呼出しのない 249 行のプログラ 厶を 0.80 秒で, また，8個の手続き，9個の大域変数 を含み，すべての手続きが㘧互いに呼び合う可能性の ある 275 行のプログラムを 1.82 秒で，それぞれ解析す ることができる、今後，このシステムをより使いやす いユーザインタフェースを備えた本格的なシステムに する予定である。

\section{文献}

(1) Weiser M.: "Program Slicing", Proceedings of the Fifth International Conference on Software Engineering, pp. 439-449(1981).

(2) Horwitz S., Reps T. and Binkley D.: "Interprocedural Slicing Using Dependence Graphs", Proceedings of the SIGPLAN '88 Conference on Programming Language Design and Implementation, pp. 35-46(1988).

(3) Horwitz S., Reps T. and Binkley D.: "Interprocedural Slicing Using Dependence Graphs", ACM Transactions on Programming Languages and Systems, 12, 1, pp. 26-60(1990).

(4) Horwitz S. and Reps T.: "The Use of Program Dependence Graphs in Software Engineering", Proceedings of the 14th International Conference on Software Engineering, pp. 392-411(1992).

(5) Hwang J.C., Du, M.W. and Chou C.R.:"Finding Pro- gram Slices for Recursive Procedures", Proceedings of the IEEE COMPSAC '88, pp. 220-227(1988).

(6) Ottenstein K.J. and Ottenstein L.M.:"The Program Dependence Graph in a Software Development Environment", Proceedings of the ACM SIGSOFT/SIGPLAN Software Engineering Symposium on Practical Software Development Environments, ACM SIGPLAN Notices 19(5) pp. 177-184(1984).

（7）下村隆夫: "Program Slicing 技術とテスト，デバッグ，保 守への応用”, 情報処理, 33, 9, pp. 1078-1086(1992).

(8) Kingston J.H.: "Algorithms and Data Structures : Design, Correctness, Analysis ", Addison-Wesley, 1990 .

（9）植田良一，練 林，井上克郎，烏居宏次: “再帰を含むプログ ラムの依存関係解析とそれに基づくプログラムスライシン グ”，信学技報, SS93-24(1993-09).

(10) Aho A.V., Sethi S. and Ullman J.D.: "Compilers : Principles, Techniques, and Tools", AddisonWesley(1986).

(11) Shimomura T.: "Bug Localization Based on ErrorCause-Chasing Methods", Transactions of information Processing Society of Japan, 34, 3, pp. 489500(1993).

(12) Harrold M. J. and Soffa M. L. :"Efficient Computation of Interprocedural Definition-Use Chains", ACM Transactions on Programming Languages and Systems, 16, 2, pp. 175-204(1994).

(13) Pande H. D., Landi W. A. and Ryder B. G. :"Interprocedural Def-Use Associations for $\mathrm{C}$ systems with Single Level Pointers", IEEE Transactions on Software Engineering, 20, 5, pp. 385-403(1994).

(平成 6 年 3 月 7 日受付, 8 月 15 日再受付)

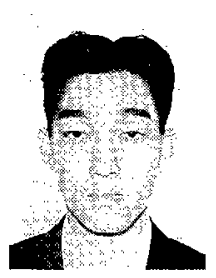

\section{植田 良一}

平 4 阪大・基礎工・情報中退．平 6 同大大 学院修士課程了. 同年日立製作所システム開 発研究所入所。プログラムスライスの研究に 従事.

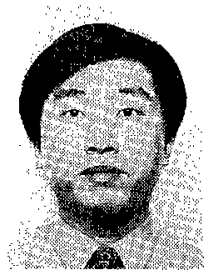

\section{練林}

昭 59 中国四川大・計算機科学系卒. 昭 62 同大修士課程了．現在阪大大学院博士後期課 程在学中.プログラムスライス，プログラム 比較ツール极よびテストプロセスの研究に 従事. 


\section{井上 克郎}

昭 54 阪大 - 基礎工 - 情報卒. 昭 59 同大大 学院博士課程了. 同年同大 - 基礎工 - 情報 助手. 昭59〜昭61ハワイ大マノア校・情報 工学科・助教授。平 1 阪大・基礎工・情報・講 師. 平 3 年 11 月同学科・助教授. 工博. ソフ トウェア工学の研究に従事. ACM, IEEE, 情報処理学会各会員.

\section{鳥居 宏次}

昭 37 阪大. 工・ 通信卒. 昭 42 同大大学院 博士課程了。同年電気試験所（現電子技術緿 合研究所）入所. 昭50ソフトウェア部言語 処理研究室室長, 昭 59 阪大・基礎工・情報 教授. 平 4 奈良先端科学技術大学院大学・教 授，阪大・基礎工・情報・教㥅併任。工博. ソ フトウェア工学の研究に従事. 情報処理学会, 日本ソフトウェア 科学会, 人工知能学会, ACM, IEEE各会員. 